\title{
Differential secretion of gonadotrophins: investigation of the role of secretogranin II and chromogranin A in the release of LH and FSH in LBT2 cells
}

\author{
L Nicol, J R McNeilly, M Stridsberg ${ }^{1}$ and A S McNeilly \\ MRC Human Reproductive Sciences Unit, Centre for Reproductive Biology, 49 Little France Crescent, Edinburgh EH16 4SB, UK \\ ${ }^{1}$ Department of Medical Sciences, Clinical Chemistry, University Hospital, S-751 85 Uppsala, Sweden \\ (Requests for offprints should be addressed to L Nicol; Email: I.nicol@ hrsu.mrc.ac.uk)
}

\begin{abstract}
This study investigated the role of the secretory granule proteins, secretogranin II (SgII) and chromogranin $\mathrm{A}(\mathrm{CgA})$, in the differential secretion of FSH and LH from L $\beta$ T2 mouse gonadotroph cells. Exogenous activin, which synergises with $\mathrm{GnRH}$, is essential for the release of $\mathrm{FSH}$ from these cells, but also has stimulatory effects on $\mathrm{LH}$ and enhances $\mathrm{GnRH}$-induced $\mathrm{LH}$ secretion. Two experiments are reported. In experiment 1 , cultures were supplemented with activin $(0-50 \mathrm{ng} / \mathrm{ml})$, with and without a daily $1 \mathrm{~h}$ treatment of $10 \mathrm{nM} \mathrm{GnRH}$, for 3 days. Protein secretion and mRNA levels were measured. In experiment 2, cells were treated with activin $(50 \mathrm{ng} / \mathrm{ml})$ alone, a daily $1 \mathrm{~h}$ treatment of $10 \mathrm{nM} \mathrm{GnRH}$, or a combination of both for 6 days. In addition, cells exposed to activin+GnRH for 3 days were subsequently left untreated or given activin or $\mathrm{GnRH}$ alone for a further 3 days for comparison with cells maintained in activin+GnRH for 6 days. Protein secretion, intracellular protein and mRNA levels were measured. FSH secretion was stimulated, dose dependently, by activin and this effect increased synergistically in the presence of GnRH. The close correlation between secreted and intracellular FSH and FSH $\beta$ mRNA levels was maintained in cells that had undergone treatment withdrawal after previous exposure to activin+GnRH, but there was no correlation between $\mathrm{FSH}$ and the granins. These results are consistent with the view that FSH released in response to activin/GnRH is constitutively secreted via a granin-independent pathway. Sgll secretion mirrored the GnRH-induced secretion of LH, but was unaffected by activin, which stimulated LH secretion and had a detrimental effect on CgA mRNA transcription. This confirms previous observations that the $\mathrm{LH}$ released in response to $\mathrm{GnRH}$ is co-released with Sgll via a regulated, granin-dependent pathway, and, in addition, suggests that activin may stimulate LH secretion through a constitutive, granin-independent pathway.
\end{abstract}

Journal of Molecular Endocrinology (2004) 32, 467-480

\section{Introduction}

The control of reproduction requires that the secretion of the gonadotrophins luteinizing hormone $(\mathrm{LH})$ and follicle-stimulating hormone (FSH) is tightly controlled, particularly in the female to allow selection and maturation of the preovulatory follicles in the ovary. LH and FSH are produced in bihormonal gonadotroph cells in the anterior pituitary (Liu et al. 1988, Currie \& McNeilly 1995, Thomas \& Clarke 1997, Crawford et al. 2002), but have distinctly different patterns of secretion (Childs et al. 1987, Lloyd \& Childs 1988). While there is some basal, non-pulsatile secretion of LH (McNeilly et al. 1991, Crawford et al. 2002), this hormone is released predominantly from intracellular stores in discrete pulses under the influence of pulsatile hypothalamic gonadotrophin-releasing hormone $(\mathrm{GnRH})$, a regulated pathway of secretion (Clarke \& Cummins 1982, Burgess \& Kelly 1987). In contrast, while there is limited pulsatile secretion of FSH, often independent of pulsatile $\mathrm{GnRH}$ (Farnworth 1995, Padmanabhan et al. 1997, Crawford et al. 2002), the bulk of this hormone appears to be constitutively secreted and thus the amount released is directly related to the rate of 
synthesis (Muyan et al. 1994, Farnworth 1995). Principally, regulation of LH release is via regulation of the pattern of pulsatile $\mathrm{GnRH}$ input (Clarke \& Cummins 1982), while that of FSH is through negative feedback of gonadal steroids, particularly oestradiol and testosterone, and inhibins, which act directly at the pituitary (Vale et al. 1988, Gharib et al. 1990, McNeilly et al. 1991, Besecke et al. 1996, Padmanabhan \& McNeilly 2001).

Since both LH and FSH are produced in, and released from, the same gonadotrophs, there must be an intracellular mechanism controlling discrete release of the gonadotrophins, which both consist of a common $\alpha$-subunit combined with a hormone-specific $\beta$-subunit and have a deduced similar tertiary structure (Lapthorn et al. 1994). A potential mechanism could involve differential intracellular packaging of $\mathrm{LH}$ and FSH within the gonadotroph, leading to different pathways of secretion. The principal cargo proteins in secretory granules are the granins, chromogranin $\mathrm{A}(\mathrm{CgA})$, chromogranin B $(\mathrm{CgB})$ and secretogranin II (SgII). These proteins aggregate at low $\mathrm{pH}$ and high $\mathrm{Ca}^{2+}$ concentrations (Yoo 1996), as found within the trans-Golgi network where granule formation is initiated, and thus have been proposed to function as helper proteins in packaging other proteins into secretory granules (Huttner \& Natori 1995). Indeed it has been suggested that $\mathrm{CgA}$ specifically acts as the master 'on/off' switch regulating secretory granule formation in neuroendocrine cells (Kim et al. 2002). We (Crawford \& McNeilly 2002, Crawford et al. 2002) and others (Watanabe et al. 1991, 1993) have shown that LH is co-packaged with SgII into electron-dense secretory granules in gonadotrophs and that pulsatile secretion of LH requires the presence of these granules (Crawford et al. 2002). Furthermore, basal secretion of LH in vivo is associated with granules containing only LH and no SgII (Crawford et al. 2002). Thus, packaging of $\mathrm{LH}$ into two different types of granule appears to determine the mode of secretion of LH.

While there is an association between levels of FSH $\beta$ mRNA, synthesis and release of FSH, and plasma FSH levels, little is known about the role that packaging of FSH may play in this type of secretion (McNeilly 1988, Farnworth 1995, McNeilly et al. 2003). FSH appears to be localised in different regions of the gonadotrophs compared with LH (Thomas \& Clarke 1997) and preliminary results suggest that FSH is associated with electron-lucent bodies and is not present within the $\mathrm{LH}+\mathrm{ve} / \mathrm{SgII}+\mathrm{ve}$ electron-dense granules (Crawford et al. 2002). Indeed, the differential pattern of LH and FSH secretion would predict that the two hormones should be in different storage granules prior to release, or such different patterns of secretion could not occur.

Previously, studies using the L $\beta$ T2 gonadotroph cell line showed that in vitro LH release in response to GnRH was closely associated with a parallel release of SgII (Nicol et al. 2002). While no clear correlation was observed between the release or storage of $\mathrm{LH}$ and $\mathrm{CgA}$, this granin has been localised to the periphery of $\mathrm{LH}+\mathrm{ve} / \mathrm{SgII}+\mathrm{ve}$ granules in the sheep pituitary (Crawford \& McNeilly 2002) as well as in light-dense vesicles containing FSH in the rat pituitary (Watanabe et al. 1991). Furthermore, we have previously shown that mRNA levels for $\mathrm{CgA}$ increased in response to GnRH, suggesting a possible role in the regulated release of LH (Nicol et al. 2002).

Early reports utilising L $\beta$ T2 cells had suggested that they were unable to synthesise and secrete FSH (Turgeon et al. 1996), so the relationship between the granins and FSH secretion was not evaluated. However, combined activin and GnRH treatment has recently been shown to stimulate FSH $\beta$ mRNA levels and subsequent secretion of FSH in these cells (Graham et al. 1999). Thus, in the present study we have utilised this finding to manipulate the patterns of synthesis and secretion of $\mathrm{FSH}$, as well as $\mathrm{LH}$, in order to evaluate interactions between the gonadotrophins and the granins. The results support the concept that FSH secretion is via a distinct intracellular pathway, independent of LH and granin release.

\section{Materials and methods}

\section{Cell culture}

L $\beta$ T2 cells were kindly provided by Dr P. Mellon (University of California, San Diego, CA, USA) and cultures were maintained as described previously (Nicol et al. 2002). For experimental purposes cells were cultured on six-well plates coated with phenol-red-free Matrigel (1:3; BD Biosciences Clontech, Cowley, Oxford, UK), in phenol-red-free Dulbecco's modified Eagle's medium (DMEM) (1 g/l glucose) supplemented 
with $10 \%$ charcoal-treated fetal calf serum, $3.5 \mathrm{~g} / 1$ glucose, $4 \mathrm{mM}$ L-glutamine, $1 \times$ nonessential amino acids, $20 \mathrm{nM}$ dexamethasone, 50 $\mathrm{U} / \mathrm{ml}$ penicillin and $50 \mu \mathrm{g} / \mathrm{ml}$ streptomycin. Cell culture reagents were obtained from Sigma unless otherwise indicated.

\section{Experiment 1}

To confirm the appropriate concentration of activin for use in subsequent experiments, an activin dose response was carried out in the presence and absence of GnRH. L $\beta$ T2 cells were seeded at a density of $2 \times 10^{6}$ cells per well (three wells per treatment group), allowed to attach overnight, then exposed to recombinant human activin A (R\&D Systems, Abingdon, Oxon, UK) at 0, 10, 20 or $50 \mathrm{ng} / \mathrm{ml}$, with and without a daily $1 \mathrm{~h}$ treatment of 10 nM GnRH (Peninsula Laboratories Europe Ltd, St Helens, Merseyside, UK), for 3 days, as described by Graham et. al (1999). Daily protein secretion and day 4 mRNA levels were measured.

\section{Experiment 2}

There were two parts to this experiment. (A) In an attempt to further stimulate levels of FSH/LH production and secretion, observed as a result of the treatment regime described above, the duration of treatment was extended. Cells were plated at a density of $1.25 \times 10^{6}$ cells/well (six wells per treatment group) and treated with activin/GnRH as described above, except that activin was used at $50 \mathrm{ng} / \mathrm{ml}$ only and the treatment period was extended to 6 days. (B) The effects of withdrawal of activin, GnRH or activin $+\mathrm{GnRH}$ from cells previously exposed to activin $+\mathrm{GnRH}$ were assessed. Cells were plated at $1.25 \times 10^{6}$ cells per well (six wells per group), treated with activin (50 ng/ml)/GnRH as described above for 3 days, then transferred to untreated or activin-only conditions or given daily $1 \mathrm{~h} \mathrm{GnRH}$ treatments only for a further 3 days and compared with cells maintained in activin + GnRH for 6 days. For both parts of this experiment daily protein secretion was measured (six wells per group). On day 7 each group was split into two: three wells for measurement of mRNA levels and three wells for measurement of intracellular protein.

Media samples were collected at each medium change for RIA to measure protein secretion. In experiment 1 all cells (day 4), and in experiment 2 half of each group (day 7) were suspended in RNazol B (Tel-Test, Inc., TX, USA) and total RNA prepared, according to the manufacturer's protocol, for quantitative reverse transcription (RT)-PGR analysis of mRNA levels. In experiment 2 the remaining cells on day 7 were used to prepare intracellular protein extracts as described previously (Nicol et al. 2002) for analysis by RIA.

\section{Radioimmunoassays}

\section{Gonadotrophins}

Secreted and intracellular FSH and LH were measured by RIA as previously described (McNeilly et al. 1996), using agents supplied by Dr A Parlow (National Institute of Diabetes and Digestive and Kidney Diseases, Torrance, CA, USA). The reference preparations were AFP-5308D and rLH-RP-1, and the minimum detectable concentrations were $1 \mathrm{ng} / \mathrm{ml}$ and $200 \mathrm{pg} / \mathrm{ml}$, for FSH and LH respectively. The intra- and inter-assay coefficients of variation were $<10 \%$ for both assays.

\section{Granins}

SgII was measured as described previously (Stridsberg et al. 1995, Nicol et al. 2002), using an antibody against the human SgII amino acid sequence 154-165 (hSgII154-165). CgA was measured using an antibody to human CgA amino acid sequence 324-337 (hCgA324-337), which detects the WE-14 region of $\mathrm{CgA}$, as described previously (Portela Gomes \& Stridsberg 2001, Nicol et al. 2002). The detection limits were $<10 \mathrm{fmol}$ and the total assay variation was $<10 \%$ for both assays.

\section{Quantitative RT-PCR}

Levels of mRNA for LH $\beta$, FSH $\beta$, SgII, CgA, GnRH receptor (GnRH-R), inhibin/activin $\beta B$ subunit and the activin receptors IIA (ARIIA), IIB (ARIIB) and IB (ARIB) were measured using quantitative Taqman RT-PCR. This was performed as described previously for LH $\beta$ (Nicol et al. 2002). Primer and probe sequences were designed using Primer Express software (PE Biosystems, Warrington, UK) and were synthesized either by PE Biosystems or by Biosource Europe S.A., 
Table 1 Sequences of primers and probes used for Taqman RT-PCR analysis

Forward Primer

\begin{tabular}{ll}
\cline { 2 - 2 } Gene & ggagagcaatctgctgccata \\
FSH $\beta$ & tgtcctagcatggtccgagtact \\
LH $\beta$ & tgtgtgaccactgcagctt \\
GnRH-R & atgtcccctgccagttca \\
$\beta B-s u b u n i t$ & aagttcgaggctggcaagtc \\
ARIIA & ggcagagtgaacgggaaatc \\
ARIIB & ccatgaagactatcaactgccgtat \\
ARIB &
\end{tabular}

Reverse primer

gcagaaacggcactcttcct
agggctacaggaaaggagactatg
tgaagaggcagcgcaaggt
ctcaggagggaaagtgcattg
caacactctggagccatatacct
gcagcaatgaactgcaacaag
caaccttcgcatctcctcaa

Probe (FAM labelled)

ctgtgaattgaccaacatcaccatctcagtaga cggctgctttgcctcctgtgc

cagtggtggcatcaggccttctacaacttt

ttgccctcccgcctgctcc

cgggtaccaacctgccatggg

cacacccggcatgaagcacgaa

acgacttagtgccctccgacccttcc
(Nivelles, Belgium). The probe and primer sets used for all sequences are shown in Table 1.

\section{Statistical analysis}

Data are reported as means \pm s.E.M. Comparisons between experimental groups were determined using one-way ANOVA, and where a significant interaction was found, post-hoc analysis was performed using Tukey's test. Analysis of interaction between activin and GnRH in the dose--response experiment was carried out using two-way ANOVA and the Bonferroni method. All statistical analyses were performed using GraphPad Prism version 4 (GraphPad software Inc., San Diego, CA, USA). $\quad P<0.05$ was considered significant.

\section{Results}

\section{Experiment 1: Activin dose response}

This experiment examined the effects of constant exposure to $0,10,20$ and $50 \mathrm{ng} / \mathrm{ml}$ activin $\mathrm{A}$ for 3 days, in the presence and absence of daily GnRH treatment, on the secretion of FSH, LH, SgII and $\mathrm{CgA}$ and on mRNA levels for FSH $\beta$, LH $\beta$, SgII and $\mathrm{CgA}$. Secretion profiles for each protein, representing the total protein secreted during the $1 \mathrm{~h} \mathrm{GnRH}$ treatment and the subsequent overnight incubation, and the corresponding day 4 mRNA levels, are depicted in Fig. 1.

\section{FSH}

Activin alone (20 and $50 \mathrm{ng} / \mathrm{ml}$ ) increased FSH secretion $(P<0 \cdot 01)$ on day 3 , whereas $\mathrm{GnRH}$ alone had no effect (Fig. 1A(i)). While activin + GnRH had a small stimulatory effect $(P<0 \cdot 01)$ on
FSH secretion even on day 1 , by days 2 and 3 the combined treatment markedly stimulated $(P<0.001)$ FSH release, in a dose-dependent manner, compared with untreated controls and individual treatments (Fig. 1A(i)). FSH $\beta$ mRNA was unaffected by individual treatments, but was up-regulated $(P<0.001)$ by activin (50 ng/ $\mathrm{ml})+$ GnRH (Fig. 1B(i)).

\section{$L H$}

All concentrations of activin stimulated $(P<0 \cdot 001)$ LH secretion on days 1 and 2 , but on day 3 only $50 \mathrm{ng} / \mathrm{ml}$ had a stimulatory $(P<0.01)$ effect (Fig. 1A(ii)). GnRH alone also stimulated $(P<0.001)$ daily LH secretion (Fig. 1A(ii)). Combined activin $+\mathrm{GnRH}$ further increased $\mathrm{LH}$ secretion $(P<0.001)$ beyond levels observed with individual treatments, but this effect was similar at all concentrations of activin (Fig. 1A(ii)). Activin $(50 \mathrm{ng} / \mathrm{ml})+\mathrm{GnRH} \quad$ increased $\quad(P<0.01) \quad \mathrm{LH} \beta$ mRNA transcription (Fig. 1B(ii)).

\section{Sgll}

Activin alone had little effect on SgII secretion overall, with only a slight increase obtained in response to $50 \mathrm{ng} / \mathrm{ml}(P<0 \cdot 05)$ on day 2 , whereas GnRH alone markedly increased $(P<0 \cdot 001)$ SgII secretion each day (Fig. 1A(iii)). On day 3 activin $(20$ and $50 \mathrm{ng} / \mathrm{ml})+\mathrm{GnRH}$ increased SgII secretion $(P<0.01$ and $P<0.001$ respectively) compared with GnRH alone (Fig. 1A(iii)). SgII mRNA levels were not significantly affected by any treatment (Fig. 1B(iii)).

\section{$\operatorname{Cg} A$}

Activin alone had no effect on $\mathrm{GgA}$ secretion, whereas GnRH stimulated (day $1, P<0.05$; days 2 


\section{A. Secretion}



Figure 1 Activin dose response. (A) Total daily secretion of (i) FSH, (ii) LH, (iii) Sgll and (iv) CgA from L $\beta T 2$ cell cultures supplemented with human recombinant activin $A(0,10,20$ and $50 \mathrm{ng} / \mathrm{ml})$, with and without a daily $1 \mathrm{~h}$ treatment of $10 \mathrm{nM} \mathrm{GnRH}$, for 3 days. Each value represents the total protein secreted during the $1 \mathrm{~h} \mathrm{GnRH}$ (or corresponding control) treatment and the subsequent overnight incubation. (B) mRNA levels for (i) FSH $\beta$, (ii) LH $\beta$, (iii) Sgll and (iv) CgA from L $\beta T 2$ cells cultured as described above and harvested on day 4. Different letters indicate significant differences between treatment groups. Values represent means \pm S.E.M.; $n=3$. 
and $3, P<0.001$ ) release of this protein (Fig. $1 \mathrm{~A}(\mathrm{iv}))$. However, when $\mathrm{GnRH}$ was combined with activin, a decrease in $\mathrm{CgA}$ release $(P<0.001)$, compared with the GnRH-stimulated levels was observed, although the amounts of $\mathrm{CgA}$ released remained higher $(P<0.05)$ than those obtained with activin alone (Fig. 1A(iv)). Activin $(50 \mathrm{ng} / \mathrm{ml})+\mathrm{GnRH}$ increased $(P<0 \cdot 05)$ CgA mRNA compared with activin alone (Fig. 1B(iv)).

The results from this experiment indicated that $50 \mathrm{ng} / \mathrm{ml}$ activin, in the presence of $\mathrm{GnRH}$, was required to have an effect on $\mathrm{FSH} \beta$ mRNA levels in L $\beta$ T2 cells. This concentration of activin also produced the greatest stimulation of FSH release and was effective in enhancing the stimulatory effects of $\mathrm{GnRH}$ on $\mathrm{LH}$ secretion. Consequently, $50 \mathrm{ng} / \mathrm{ml}$ activin was used in the subsequent experiments.

\section{Experiment 2(A): effects of 6 days treatment with activin, GnRH and activin+GnRH}

The effects of constant exposure to $50 \mathrm{ng} / \mathrm{ml}$ activin $\mathrm{A}$, in the presence and absence of a daily $1 \mathrm{~h}$ treatment of $10 \mathrm{nM} \mathrm{GnRH}$, for 6 days, on the secretion (day 3 and day 6 results are reported) and intracellular storage (on day 7) of FSH, LH, SgII and $\mathrm{CgA}$ were determined. In addition, day 7 FSH $\beta, \mathrm{LH} \beta, \mathrm{SgII}, \mathrm{CgA}, \mathrm{GnRH}-\mathrm{R}, \beta \mathrm{B}$-subunit and activin receptor (IB, IIA and IIB) mRNA levels were measured.

\section{$\mathrm{FSH}$}

Activin $+\mathrm{GnRH}$ increased $(P<0.001)$ FSH secretion on days 3 (Fig. 2A(i)) and 6 (Fig. 2B(i)), whereas individual treatments had no effect. Similarly, intracellular FSH (Fig. 2C(i)) and FSH $\beta$ mRNA (Fig. 2D(i)) levels increased $(P<0.001)$ in response to activin $+\mathrm{GnRH}$ only.

\section{$L H$}

On day 3, activin alone $(P<0.01)$ and GnRH alone $(P<0.001)$ both increased LH secretion, with GnRH producing the higher $(P<0 \cdot 01)$ response (Fig. 2A(ii)). Combined activin $+\mathrm{GnRH}$ enhanced $(P<0.001)$ LH secretion approximately 2-fold compared with individual treatments. Activin alone $(P<0.01)$ and $\mathrm{GnRH}$ alone $(P<0.05)$ increased
LH secretion on day 6 also, but there was no difference between these two responses (Fig. 2B(ii)). Combined activin $+\mathrm{GnRH}$ again enhanced $(P<0.001) \mathrm{LH}$ secretion compared with individual treatments (Fig. 2B(ii)). Intracellular LH and LH $\beta$ mRNA were increased $(P<0 \cdot 01$, Fig. $2 \mathrm{C}$ (ii) and $P<0 \cdot 05$, Fig. 2D(ii) respectively) by activin+ GnRH.

\section{Sgll}

GnRH alone increased $(P<0 \cdot 001)$ SgII secretion on days 3 and 6 (Fig. 2A (iii) and 2B (iii) respectively). Activin had no effect on SgII release. However, activin increased $(P<0.05)$ intracellular SgII (Fig. 2G(iii)), whereas GnRH and activin+ GnRH reduced $(P<0.01$ and $P<0.05$ respectively) intracellular levels of this protein (Fig. 2G(iii)).

\section{$\operatorname{Cg} A$}

GnRH increased $(P<0.001)$ GgA secretion on day 3. However, when GnRH was combined with activin, $\mathrm{CgA}$ secretion was similar to control levels (Fig. 2A(iv)). After 6 days of treatment there were no differences in secretion or intracellular protein levels (Fig. 2B(iv)). While CgA mRNA from all treatment groups was unchanged compared with controls, GnRH-stimulated cells had significantly higher $(P<0.05)$ levels of this mRNA compared with cells treated with activin alone (Fig. 2D(iv)).

\section{GnRH receptor, $\beta B$-subunit and activin receptor $m R N A s$}

GnRH-R mRNA levels were increased $(P<0.05)$ by activin + GnRH (Fig. 3A(i)). $\beta B$-subunit mRNA from all treatment groups was unchanged compared with controls, but was lower $(P<0.05)$ in GnRH-treated cells compared with activin-treated cells (Fig. 3A(iii)). Activin receptor mRNA levels were unchanged by the treatments given (data not shown).

\section{Experiment 2(B): effects of activin, GnRH or activin+GnRH withdrawal after prior exposure to activin+GnRH}

After exposure to activin plus daily $\mathrm{GnRH}$ treatment, for 3 days, cells were transferred to either untreated medium $(\mathrm{AG} / \mathrm{C})$ or given activin 
FSH

내

Sgll

$\underline{\operatorname{CgA}}$

A. Day 3 secretion

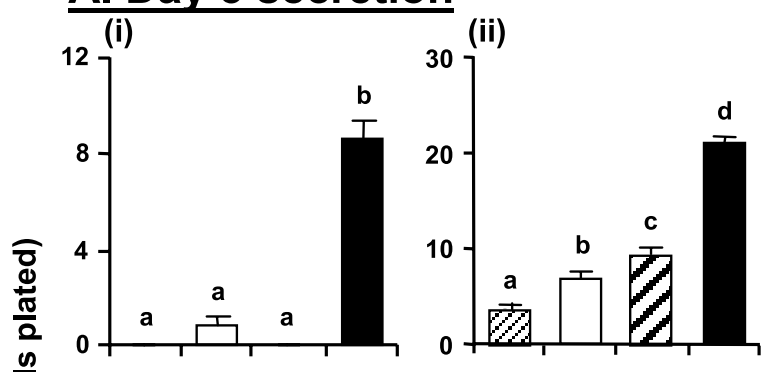

B. Day 6 secretion
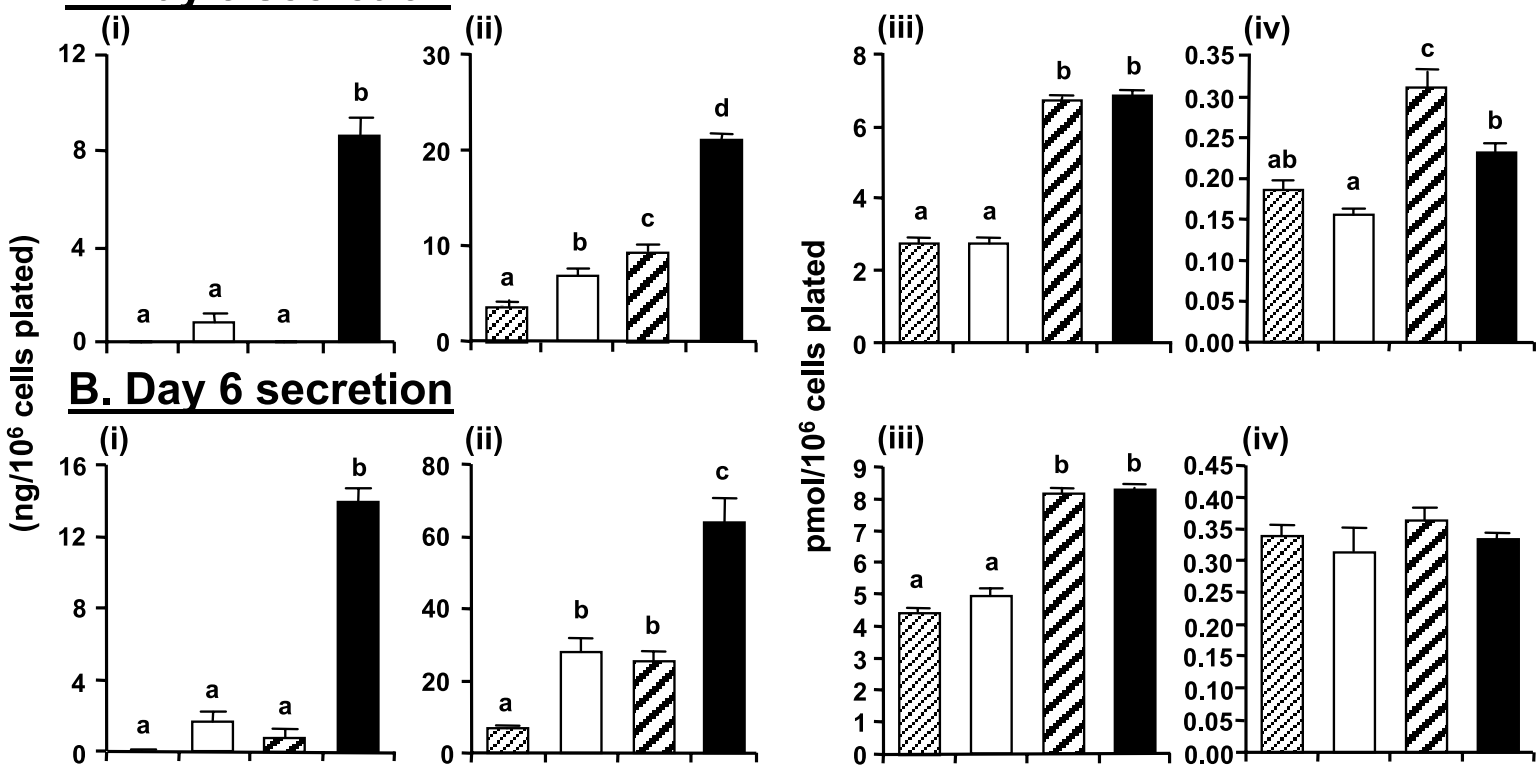

\section{Cell content}
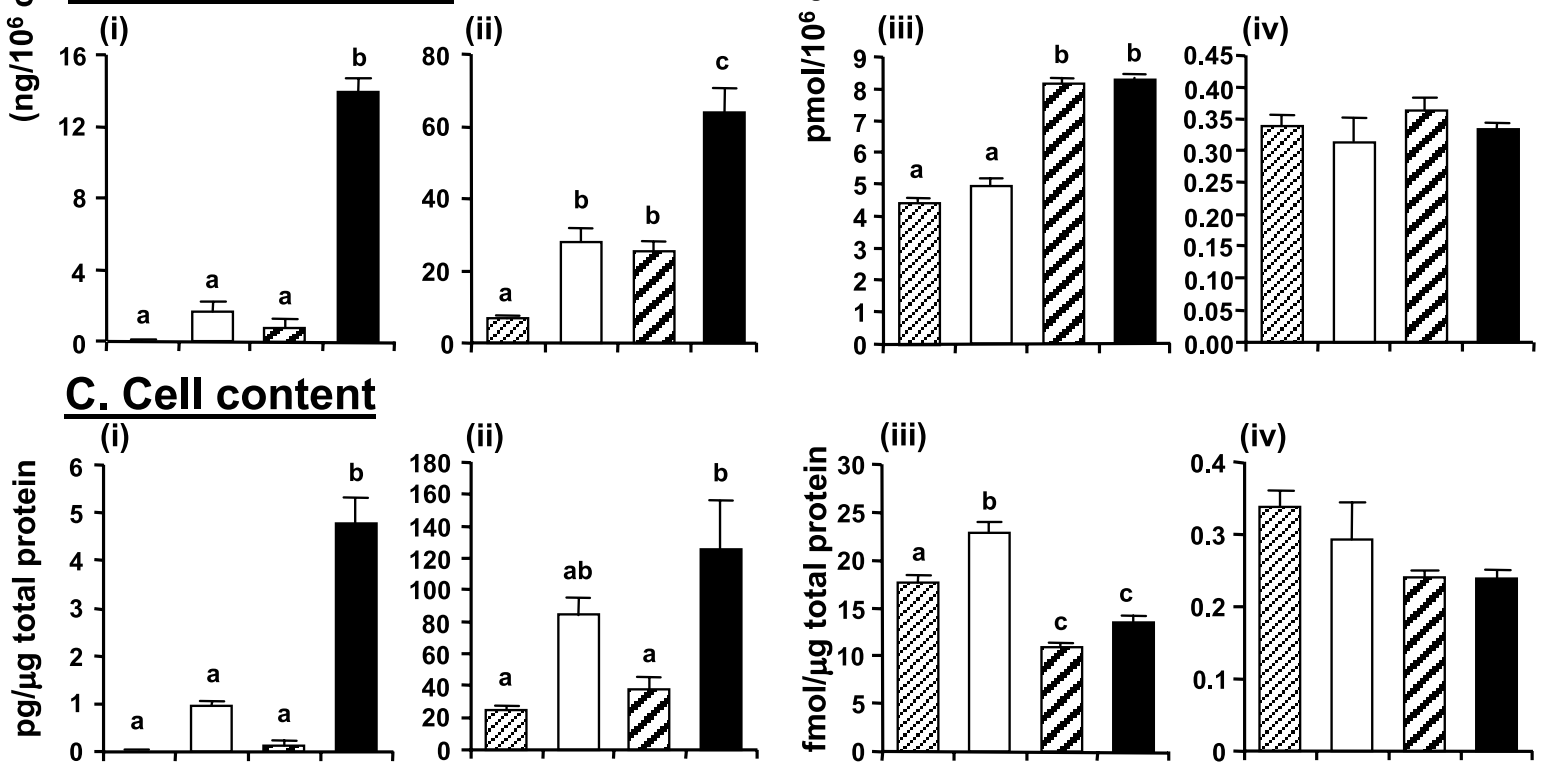

\section{D. mRNA levels}
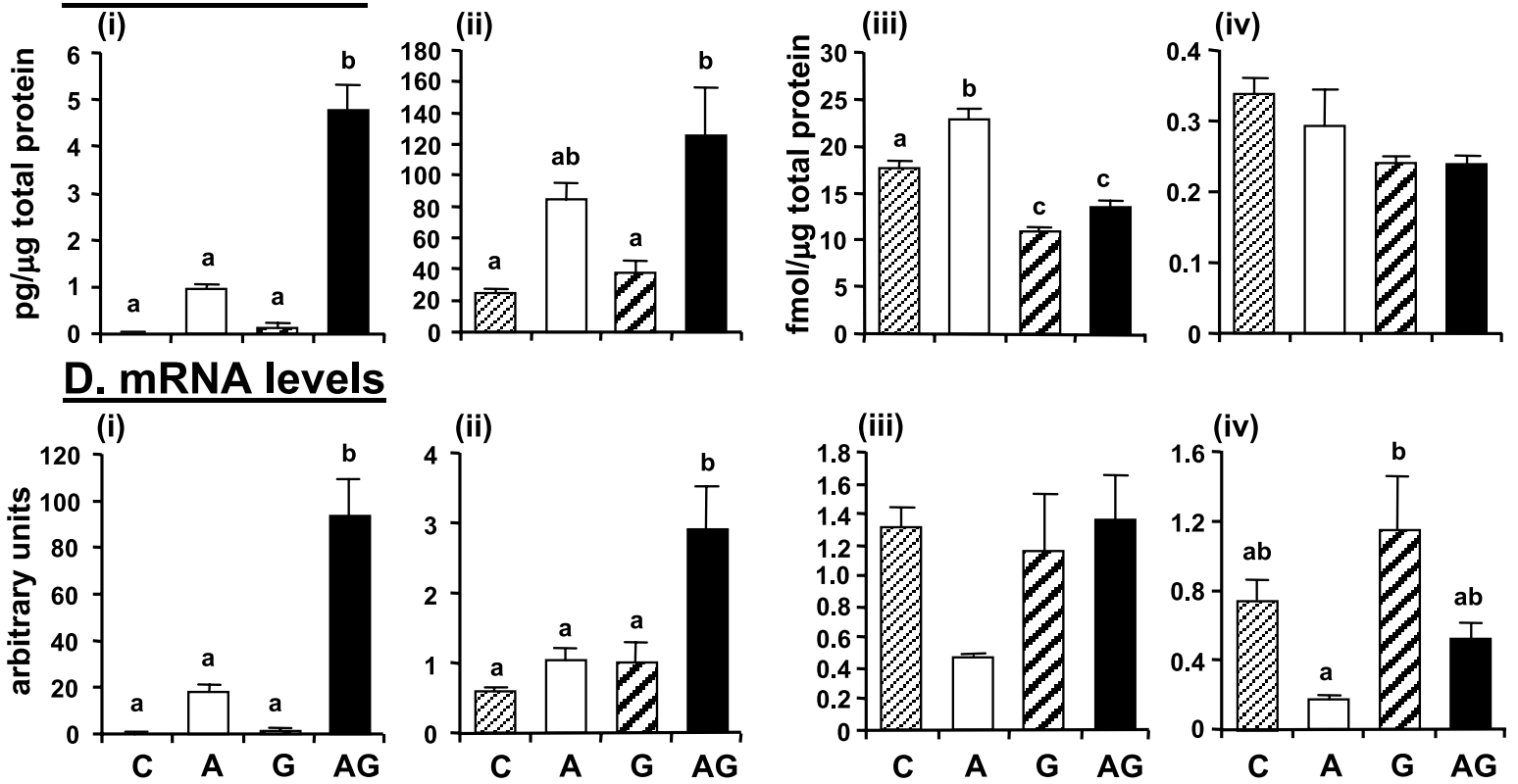

\section{Treatment Groups}

Figure 2 Effects of continual exposure to activin, GnRH and activin+GnRH for 6 days. (A) Day 3 secretion of (i) FSH, (ii) $\mathrm{LH}$, (iii) Sgll and (iv) $\mathrm{CgA}$ from $\mathrm{L} \beta \mathrm{T} 2$ cell cultures supplemented with human recombinant activin $\mathrm{A}(50 \mathrm{ng} / \mathrm{ml})$, in the presence (AG) and absence (A) of a daily $1 \mathrm{~h}$ treatment of $10 \mathrm{nM} \mathrm{GnRH}$, or with GnRH alone $(\mathrm{G})$ for 6 days. Each value represents the total protein secreted during the $1 \mathrm{~h} \mathrm{GnRH}$ (or corresponding control) treatment and the subsequent overnight incubation. (B) Day 6 secretion of (i) FSH, (ii) LH, (iii) Sgll and (iv) CgA from L $\beta$ T2 cells cultured as described. (C) Intracellular levels of (i) FSH, (ii) LH, (iii) Sgll and (iv) CgA in L $\beta$ T2 cells cultured as described and harvested on day 7. (D) mRNA levels for (i) FSH $\beta$, (ii) LH $\beta$, (iii) Sgll and (iv) CgA in L $\beta$ T2 cells cultured as described and harvested on day 7 . Different letters indicate significant differences between treatment groups. Values represent means \pm S.E.M.; $n=6$ (A and $B), n=3$ (C and D). 
(AG/A) or GnRH (AG/G) alone and cultured for a further 3 days (see Fig. 4A). Results were compared with those from cells maintained in activin $+\mathrm{GnRH}$ (AG) for the duration of the experiment.

To demonstrate the immediate effects of the treatment changes Fig. 4B depicts protein secretion in the transition period from day 3, with all cells still under the effects of activin $+\mathrm{GnRH}$, over to day 4 , the first day of treatment withdrawal. Day 3 secretion for all four groups treated with activin + GnRH was similar so results for one group only are shown. Compared with cells maintained in activin + GnRH, FSH secretion on day 4 (Fig. $4 \mathrm{~B}(\mathrm{i})$ ) was reduced (AG/C and AG/G, $P<0.001 ; \mathrm{AG} / \mathrm{A}$, $P<0.05)$ in all groups where individual or combined treatments were withdrawn. However, cells transferred to activin only continued to secrete more FSH than cells transferred to control medium $(P<0 \cdot 05)$ or given GnRH only $(P<0 \cdot 01)$. LH secretion in cells transferred to untreated or activin-only conditions was slightly reduced on day 4, compared with activin+GnRH-treated cells, but this did not reach significance (Fig. 4B(ii)). Cells transferred to GnRH only had unchanged LH secretion compared with activin $+\mathrm{GnRH}$-treated cells, but secreted significantly more $(P<0 \cdot 01)$ LH compared with cells cultured in the absence of GnRH (Fig. 4B(ii)). SgII secretion was reduced $(P<0.001)$ in cells transferred to untreated or activin-only conditions, compared with cells maintained in activin $+\mathrm{GnRH}$ or those given $\mathrm{GnRH}$ only (Fig. 4B(iii)). Day $4 \mathrm{CgA}$ secretion was unchanged by withdrawal of $\mathrm{GnRH}$ and activin+ GnRH (Fig. 4B(iv)). However, withdrawal of activin, but continued $\mathrm{GnRH}$, resulted in increased $\mathrm{CgA}$ compared with all other groups (AG, $P<0 \cdot 05$; $\mathrm{AG} / \mathrm{C}$ and AG/A, $P<0 \cdot 001)$.

Day 6 protein secretion and day 7 intracellular protein and mRNA levels are shown in Fig. 5.

\section{FSH}

Withdrawl of GnRH; but continued activinreduced $(P<0.001)$ FSH secretion to approximately half that from cells maintained in activin $+\mathrm{GnRH}$, whereas withdrawal of activin $\pm \mathrm{GnRH}$ resulted in basal levels (see Fig. 2B(i)) of FSH secretion (Fig. 5A(i)). Similar results were obtained for intracellular protein (Fig. 5B(i)) and FSH $\beta$ mRNA levels (Fig. $5 \mathrm{C}(\mathrm{i})$ ), but in the latter case levels were maintained closer to those in



Figure 3 (A) Effects of continual exposure to activin, $\mathrm{GnRH}$ and activin+GnRH for 6 days; mRNA levels for (i) GnRH-R and (ii) activin/inhibin $\beta B$-subunit in L $\beta T 2$ cell cultures supplemented with human recombinant activin A $(50 \mathrm{ng} / \mathrm{ml})$, in the presence (AG) and absence (A) of a daily $1 \mathrm{~h}$ treatment of $10 \mathrm{nM} \mathrm{GnRH}$, or with $\mathrm{GnRH}$ alone (G) for 6 days. (B) Effects of individual or combined treatment withdrawal in cells previously exposed to activin+GnRH for 3 days; mRNA levels are shown for (i) GnRH-R and (ii) activin/inhibin $\beta B$-subunit in L $\beta T 2$ cell cultures supplemented with human recombinant activin A $(50 \mathrm{ng} / \mathrm{ml})$ in the presence of a daily $1 \mathrm{~h}$ treatment of $10 \mathrm{nM}$ GnRH for 3 days, then transferred to untreated (AG/C), activin only (AG/A) or GnRH only (AG/G) conditions, and cultured for a further 3 days and compared with cells maintained in activin+GnRH (AG) for 6 days. All cells were harvested on day 7 . Different letters indicate significant differences between treatment groups. Values represent means \pm S.E.M.; $n=3$.

activin $+\mathrm{GnRH}$-treated cells by continued activin treatment.

$L H$

LH secretion was reduced $(P<0 \cdot 01)$, compared with activin $+\mathrm{GnRH}$-treated cultures, in cells transferred to untreated or activin-only conditions (Fig. 5A(ii)), whereas there were no significant changes in intracellular LH levels in response to any of the treatment regimes (Fig. $5 \mathrm{~B}(\mathrm{ii})$ ). $\mathrm{LH} \beta$ 

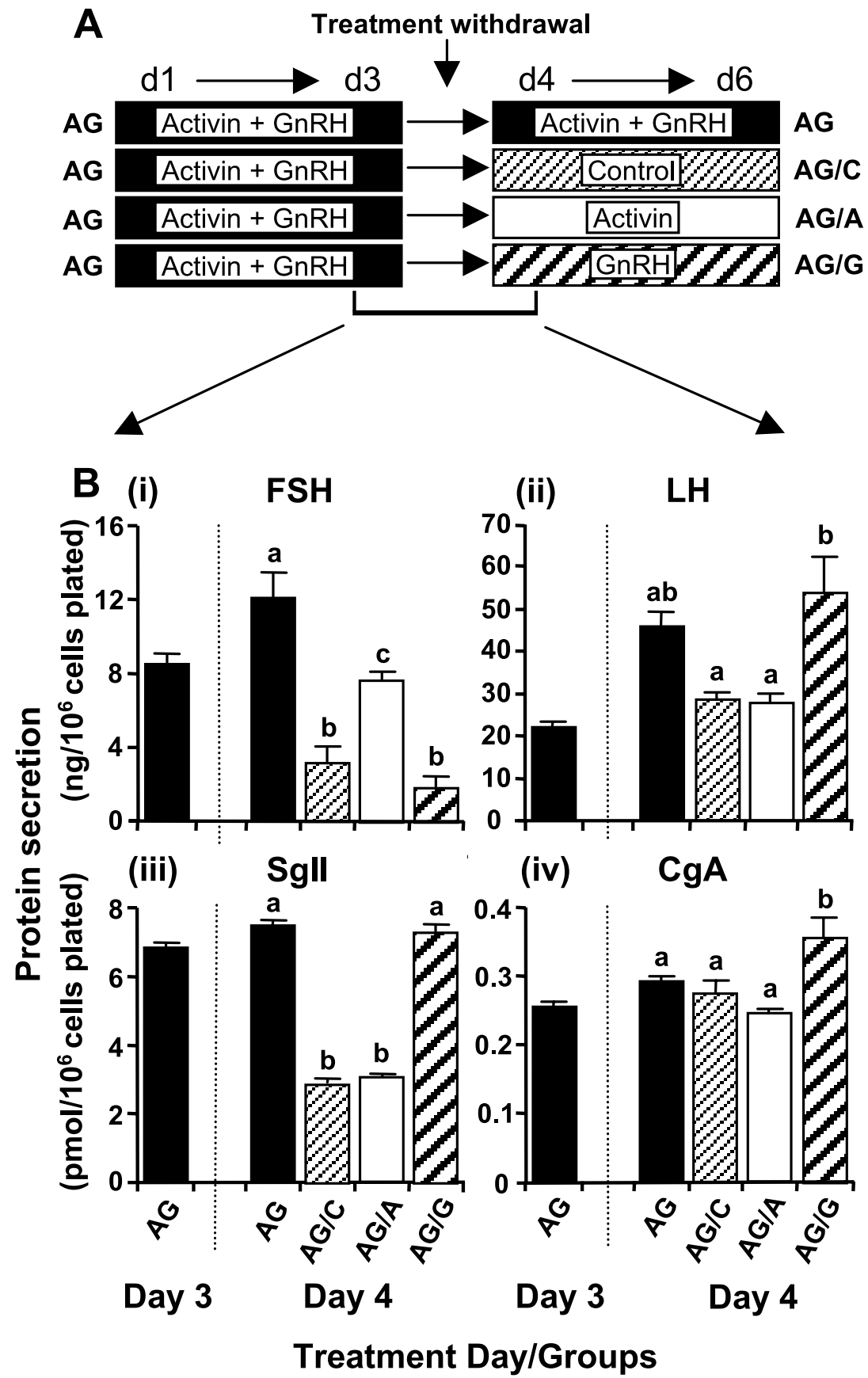

Figure 4 Effects of individual or combined treatment withdrawal in cells previously exposed to activin+GnRH: protein secretion on days 3 and 4. (A) Treatment protocol. L $\beta$ T2 cells were cultured in human recombinant activin A $(50 \mathrm{ng} / \mathrm{ml})$, in the presence of a daily $1 \mathrm{~h}$ treatment of $10 \mathrm{nM} \mathrm{GnRH}(A G)$, for 3 days, then transferred to untreated $(A G / C)$, activin only $(A G / A)$ or $G n R H$ only $(A G / G)$ conditions and cultured for a further 3 days, and compared with cells maintained in activin+GnRH (AG) for 6 days. (B) Day 3 (prior to treatment withdrawal) and day 4 (after treatment withdrawal) secretion of (i) FSH, (ii) LH, (iii) Sgll and (iv) $\mathrm{CgA}$ from L $\beta \mathrm{T} 2$ cells cultured as described above. Each value represents the total protein secreted during the $1 \mathrm{~h} \mathrm{GnRH}$ (or corresponding control) treatment and the subsequent overnight incubation. Different letters indicate significant differences between treatment groups. Values represent means \pm S.E.M.; $n=6$. 
FSH

내

Sgll

$\underline{\mathrm{CgA}}$

A. Secretion

(i)



B. Cell content
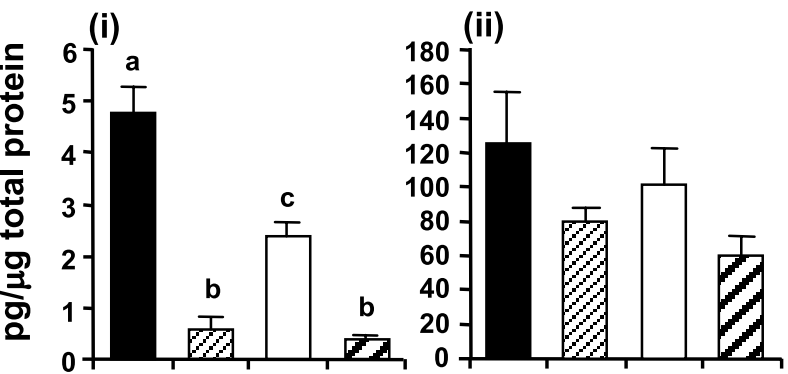

\section{C. mRNA}
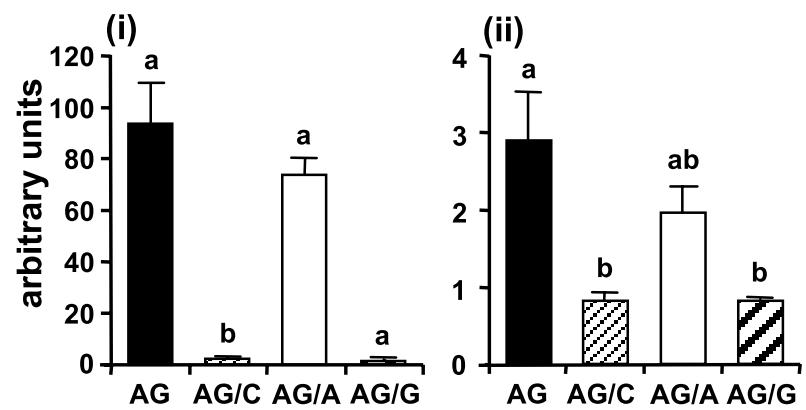

(ii)
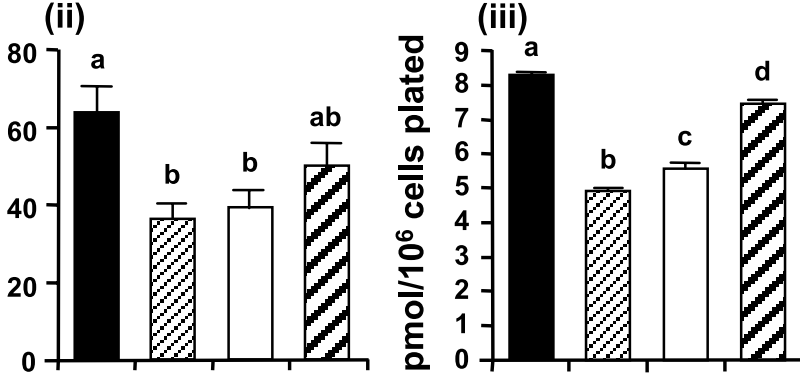

(iv)

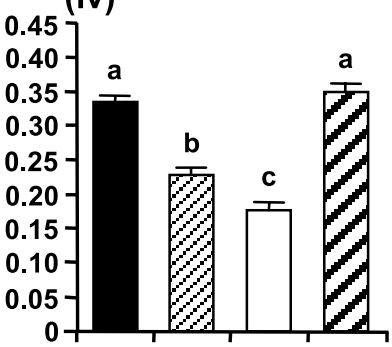

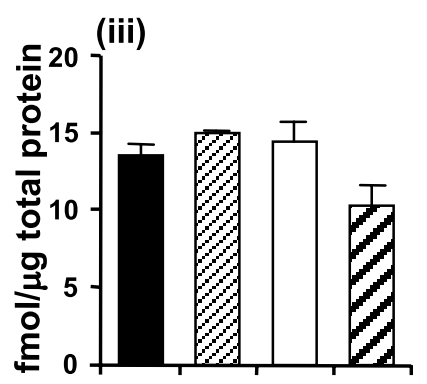
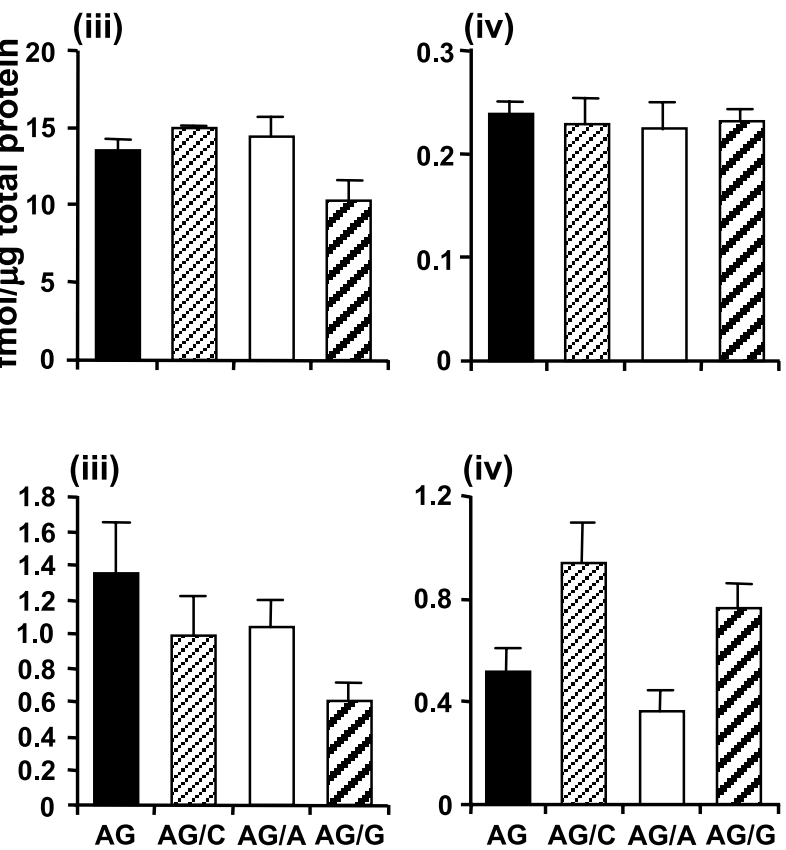

Treatment Groups

Figure 5 Effects of individual or combined treatment withdrawal in cells previously exposed to activin+GnRH. (A) Day 6 secretion of (i) $\mathrm{FSH}$, (ii) $\mathrm{LH}$, (iii) Sgll and (iv) $\mathrm{CgA}$ from $\mathrm{L} \beta \mathrm{T} 2$ cells cultured in human recombinant activin $\mathrm{A}$ $(50 \mathrm{ng} / \mathrm{ml})$, in the presence of a daily $1 \mathrm{~h}$ treatment of $10 \mathrm{nM} \mathrm{GnRH}$, for 3 days, then transferred to untreated $(A G / C)$, activin-only $(\mathrm{AG} / \mathrm{A})$ or $\mathrm{GnRH}$-only $(\mathrm{AG} / \mathrm{G})$ conditions and cultured for a further 3 days, and compared with cells maintained in activin+GnRH (AG) for 6 days. (B) Intracellular levels of (i) FSH, (ii) LH, (iii) Sgll and (iv) CgA in L $\beta T 2$ cells cultured as described above and harvested on day 7. (C) mRNA levels for (i) FSH $\beta$, (ii) LH $\beta$, (iii) Sgll and (iv) $\mathrm{CgA}$ in L $\beta T 2$ cells cultured as described above and harvested on day 7. Different letters indicate significant differences between treatment groups. Values represent means \pm S.E.M.; $n=6(A), n=3$ (B and C).

mRNA levels were reduced $(P<0 \cdot 05)$ after transfer to untreated or GnRH-only conditions, and, while there was a small reduction after transfer to activin only, this did not reach significance (Fig. 5C(ii)).
Sgll

Withdrawal of all treatments reduced $(P<0.001)$ SgII secretion compared with activin $+\mathrm{GnRH}-$ treated cells. However, activin-stimulated cells secreted more $(P<0.001)$ SgII than cells trans- 
ferred to untreated conditions, and GnRH-treated cells released more $(P<0.001)$ SgII compared with cells transferred to activin only (Fig. 5A(iii)).

\section{$\operatorname{Cg} A$}

Withdrawal of GnRH and activin $+\mathrm{GnRH}$ reduced $(P<0.001)$ CgA secretion compared with activin+ GnRH-treated cells, whereas cells that continued to receive daily $\mathrm{GnRH}$ secreted similar amounts of CgA as activin+GnRH-treated cells (Fig. 5A(iv)).

\section{GnRH receptor, activin $\beta B$-subunit and activin receptor mRNAs}

Activin and activin $+\mathrm{GnRH}$ withdrawal reduced $(P<0 \cdot 05)$ GnRH-R mRNA levels, compared with activin+GnRH-treated cells (Fig. 3B(i)), but had no significant effects on $\beta \mathrm{B}$-subunit mRNA levels (Fig. $3 \mathrm{~B}(\mathrm{ii})$ ) or on activin receptor mRNA (data not shown).

\section{Discussion}

Previously we have demonstrated a close correlation between the $\mathrm{GnRH}$-stimulated release of both LH and SgII in vitro (Nicol et al. 2002), and the co-localisation and co-release of $\mathrm{LH}$ and $\mathrm{SgII}$ in vivo (Crawford et al. 2002), suggesting that SgII plays an important role in the regulated secretion of LH. In the current report we have extended these studies to examine in detail the relationship between the synthesis, storage and secretion of FSH, as well as $\mathrm{LH}$ and the granins in L $\beta \mathrm{T} 2$ cells, to investigate further the role of granin proteins in the differential secretion of the gonadotrophins.

Early studies on L $\beta$ T2 cells indicated that they did not express FSH $\beta$ mRNA or secrete FSH (Turgeon et al. 1996). The ability of activin $( \pm \mathrm{GnRH})$ to stimulate FSH production in these cells has since been reported (Graham et al. 1999, Pernasetti et al. 2001), which has further elevated the importance of the L $\beta$ T2 cell line as a model for investigating gonadotroph function. It must be recognised, however, that the use of these immortalised cell lines can only give an indication of potential mechanisms involved in differential LH and FSH secretion and may not completely, or accurately, reflect gonadotroph function in vivo.
Nevertheless, they do provide a reproducible model gonadotroph system with which to explore potential in vivo mechanisms.

While FSH secretion in L $\beta$ T2 cells was stimulated, in a dose-dependent manner, by activin alone, and was unaffected by GnRH alone, there was a synergistic effect between the two treatments. In contrast to the previous report (Graham et al. 1999), we observed a significantly higher maximal FSH response (approx 11-fold after $72 \mathrm{~h}$ ) to activin in the presence of GnRH compared with activin alone. Very similar response patterns were obtained for secreted and intracellular FSH and FSH $\beta$ mRNA levels. This correlation was maintained in cells subjected to treatment withdrawal after previous exposure to activin $+\mathrm{GnRH}$. The close correlation between stored and secreted FSH, and FSH $\beta$ mRNA levels, and the lack of any correlation between the secretion of FSH and that of the granins, lead to the conclusion that the FSH produced in L $\beta$ T2 cells under activin/GnRH stimulation is constitutively secreted via a granin-independent pathway. Since GnRH is ineffective in stimulating or maintaining FSH production in the absence of exogenous activin, endogenous activin would appear to be absent or at very low levels in L $\beta$ T2 cells, despite the fact that they do express $\beta B$-subunit mRNA (see Fig. 3), and this presumably is one of the reasons why FSH was reportedly absent from these cells in earlier experiments (Turgeon et al. 1996).

While the effect of the interaction between activin and GnRH on FSH production and secretion has been previously noted (Weiss et al. 1992, 1993), the exact nature of the interaction is still unclear. While activin alone stimulated FSH secretion as described previously (Graham et al. 1999) it appears that GnRH requires the presence of activin in order to exert its actions. Furthermore activin alone was able to maintain FSH $\beta$ mRNA at the levels induced by activin $+\mathrm{GnRH}$ when GnRH stimulation has been removed, possibly due to post-transcriptional effects on FSH $\beta$ mRNA stability (Carroll et al. 1991). In perifused rat pituitary cultures GnRH at least doubled the increase in FSH $\beta$ mRNA induced by exogenous activin (Weiss et al. 1993), and it is estimated that GnRH controls about $50-67 \%$ of FSH $\beta$ mRNA levels at a particular concentration of activin (Miller et al. 2002). Studies in GH3 cells engineered 
to express the rat GnRH-R (rGnRH-R) and in L $\beta$ T2 cells have indicated the presence of GnRH-responsive elements (enhancers) on the rat and ovine FSH $\beta$ (oFS $\beta$ ) promoters (Kaiser et al. 1995, Pernasetti et al. 2001) and it has been reported that two activating protein-1-like enhancers on the oFSH $\beta$ proximal promoter are required for $\mathrm{GnRH}$ induction of oFSH $\beta$-Luc transcription (Strahl et al. 1998), suggesting a mechanism whereby GnRH can directly influence FSH $\beta$ transcription (Miller et al. 2002). Regardless of the mechanisms by which activin and GnRH increase or maintain FSH $\beta$ mRNA levels, the present results, showing a close relationship between FSH $\beta$ mRNA levels and the secretion of $\mathrm{FSH}$, are compatible with the concept of release of FSH mainly through a constitutive, granin-independent pathway.

Activin also had a stimulatory effect on LH secretion, although this response was not dose dependent. After 6 days of treatment the amount of LH secreted in response to activin was similar to that released in response to GnRH. Combined activin $+\mathrm{GnRH}$ induced a further increase over individual treatment levels, which appeared to be additive rather than synergistic. Activin A has previously been shown to stimulate the synthesis of GnRH receptors, through a different mechanism from GnRH (Braden \& Conn 1992) and, although neither activin nor $\mathrm{GnRH}$ alone appeared to have any effect on GnRH-R mRNA levels in this study, there was a significant increase after the combined treatment, and this may be one mechanism whereby the activin/GnRH-stimulated secretion of $\mathrm{LH}$ and FSH is regulated.

SgII secretion, in contrast to that of $\mathrm{LH}$, was stimulated only by $\mathrm{GnRH}$, and combined activin/ $\mathrm{GnRH}$ produced no additive or synergistic effects. The present results suggest that the LH released in response to $\mathrm{GnRH}$ is co-released with $\mathrm{SgII}$ via a regulated secretory pathway and that the activinstimulated LH release is probably via a constitutive, SgII-granule-independent pathway. It is likely that this pathway of release is also $\mathrm{CgA}$ independent, as activin had a detrimental effect on $\mathrm{CgA}$ mRNA levels and CgA secretion. Studies in mice have indicated that $\mathrm{LH}+\mathrm{ve} / \mathrm{SgII}$ - ve storage granules are released constitutively to maintain basal LH concentrations (Crawford et al. 2002) and it is possible that activin may be influencing the amount of LH which is directed into this type of granule. While intracellular SgII was reduced in GnRH- and activin $+\mathrm{GnRH}$-stimulated cells, presumably reflecting the ongoing secretion of $\mathrm{LH}+\mathrm{ve} / \mathrm{SgII}+\mathrm{ve}$ granules in response to $\mathrm{GnRH}$, levels were increased in activin-stimulated cells. Intracellular LH was also raised in activin-treated cells. This raises the possibility that, due to the lack of $\mathrm{GnRH}$ input and the associated regulatory pathway stimulation and release, there was an increase in the number of $\mathrm{LH}+\mathrm{ve} / \mathrm{SgII}+\mathrm{ve}$ granules in activin-treated cells as seen in vivo after GnRH immunoneutralisation in mice (Crawford et al. 2002).

The aggregative properties of SgII within the trans-Golgi network are considered to be important in facilitating the packaging of $\mathrm{LH}$ into $\mathrm{LH}+\mathrm{ve} /$ SgII+ve secretory granules, thus controlling the LH available for release through the regulated pathway, in response to $\mathrm{GnRH}$ stimulation (Gerdes et al. 1989, Watanabe et al. 1991, Crawford \& McNeilly 2002, Grawford et al. 2002). However the lack of evidence for the presence of SgIIonly granules in mouse or sheep gonadotrophs (Crawford \& McNeilly 2002, Crawford et al. 2002) suggests that LH may have more influence on the formation of $\mathrm{LH}+\mathrm{ve} / \mathrm{SgII}+\mathrm{ve}$ gonadotroph secretory granules than was previously predicted and may actually have an active role in the co-aggregation with SgII during granule formation. A role for SgII in the GnRH responsiveness of secretory granules at the time of granule exocytosis has also been envisaged (Crawford et al. 2002), but it may be that $\mathrm{CgA}$ contributes more to this effect than SgII (see below).

$\mathrm{CgA}$ secretion was maintained by $\mathrm{GnRH}$ and reduced below control levels by transfer to activin only, confirming the effects of $\mathrm{GnRH}$ and activin on secretion of $\mathrm{CgA}$ that were observed in the other experiments described here and in our previous study (Nicol et al. 2002). With the concomitant up-regulation of $\mathrm{FSH} \beta$ and down-regulation of CgA gene expression in response to activin, it would appear counter-intuitive to conclude that $\mathrm{CgA}$ played a major role in the constitutive secretion of FSH. However, there is evidence to suggest that $\mathrm{CgA}$ and $\mathrm{FSH}$ are found within the same type of granule within gonadotrophs (Watanabe et al. 1991) and that CgA+ve granules increase in number shortly after the LH surge, at a time of higher plasma FSH concentrations (Watanabe et al. 1998). Thus a role for CgA in exocytosis associated with the constitutive pathway 
cannot be ruled out and will require further investigation.

While CgA has been proposed as the master 'on/off' switch regulating the formation of densecore secretory granules (Kim et al. 2002), the precise role of $\mathrm{GgA}$ in the regulated pathway of secretion remains to be fully explained. $\mathrm{CgA}$ within gonadotrophs appears punctate, thought to be due to compartmentalisation of this granin at the granule periphery (Crawford \& McNeilly 2002, Crawford et al. 2002). In addition, inositol trisphosphate receptors $\left(\mathrm{IP}_{3} \mathrm{Rs}\right)$ on secretory granule membranes have been shown to interact with $\mathrm{IP}_{3} \mathrm{R}$ binding sites on $\mathrm{CgA}$ (Yoo \& Jeon 2000), thus contributing to intracellular $\mathrm{Ca}^{2+}$ control mechanisms and influencing regulated secretion. Together, these findings suggest that $\mathrm{CgA}$ may have an important role in granule exocytosis, but results in the current study, and in our previous report (Nicol et al. 2002), indicate that the release of $\mathrm{CgA}$ in response to $\mathrm{GnRH}$ does not correlate with that of $\mathrm{LH}$, which suggests that $\mathrm{CgA}$ may be retained within the cell along with the associated granule membrane (Crawford et al. 2002).

In summary, the results reported in this study demonstrate that activin-/GnRH-induced FSH secretion in L $\beta \mathrm{T} 2$ cells is directly related to the rate of FSH synthesis and shows no correlation with either $\mathrm{SgII}$ or $\mathrm{CgA}$, and thus appears to be released via a constitutive, granin-independent pathway. The activin-stimulated release of $\mathrm{LH}$ also appears to be granin-independent, suggesting constitutive release. In contrast, GnRH-induced secretion of LH correlates with that of SgII, and appears to involve CgA, suggesting release via a granin-related, regulated pathway. Further studies, involving the direct manipulation of granin levels, will be required to determine the precise role of these proteins in gonadotrophin secretion. However, the results presented here contribute further evidence for the importance of the specialised secretory granule proteins, SgII and $\mathrm{CgA}$, in the differential secretion of the gonadotrophins.

\section{Acknowledgements}

We thank Janet Crawford for many helpful discussions and Dr A Parlow, NIDDK, for supplying some of the reagents.

\section{Funding}

This study was supported by the Medical Research Council.

\section{References}

Besecke LM, Guender MJ, Schneyer AL, Bauer-Dantoin AG, Jameson JL \& Weiss J 1996 Gonadotropin-releasing hormone regulates follicle-stimulating hormone- $\beta$ gene expression through an activin/follistatin autocrine or paracrine loop. Endocrinology 137 3667-3673.

Braden TD \& Conn PM 1992 Activin-A stimulates the synthesis of gonadotropin-releasing hormone receptors. Endocrinology 130 2101-2105.

Burgess TL \& Kelly R 1987 Constitutive and regulated secretion of proteins. Annual Review of Cell Biology 3 243-293.

Carroll RS, Corrigan AZ, Vale W \& Chin WW 1991 Activin stabilizes follicle-stimulating hormone-beta messenger ribonucleic acid levels. Endocrinology 129 1721-1726.

Childs GV, Unabia G, Tibolt R \& Lloyd JM 1987 Cytological factors that support nonparallel secretion of luteinizing hormone and follicle-stimulating hormone during the estrous cycle. Endocrinology 121 1801-1813.

Clarke IJ \& Cummins JT 1982 The temporal relationship between gonadotropin releasing hormone $(\mathrm{GnRH})$ and luteinizing hormone (LH) secretion in ovariectomized ewes. Endocrinology 111 $1737-1739$.

Crawford JL \& McNeilly AS 2002 Co-localisation of gonadotrophins and granins in gonadotrophs at different stages of the oestrous cycle in sheep. Fournal of Endocrinology 174 179-194.

Crawford JL, McNeilly JR, Nicol L \& McNeilly AS 2002 Promotion of intragranular co-aggregation with $\mathrm{LH}$ by enhancement of secretogranin II storage resulted in increased intracellular granule storage in gonadotrophs of $\mathrm{GnRH}$-deprived male mice. Reproduction 124 267-277.

Currie RJW \& McNeilly AS 1995 Mobilisation of LH secretory granules in gonadotrophs in relation to gene expression, synthesis and secretion of LH during the preovulatory phase of the sheep oestrous cycle. Fournal of Endocrinology 147 259-270.

Farnworth PG 1995 Gonadotrophin secretion revisited. How many ways can FSH leave a gonadotroph? Fournal of Endocrinology 145 387-395.

Gerdes H-H, Rosa P, Phillips E, Baeurle PA, Frank R, Argis P \& Huttner WB 1989 The primary structure of human secretogranin II, a widespread tyrosine-sulfated secretory granule protein that exhibits low $\mathrm{pH}$ and calcium induced aggregation. Fournal of Biological Chemistry 264 12009-12015.

Gharib SD, Wierman ME, Shupnik MA \& Chin WW 1990 Molecular biology of the pituitary gonadotrophins. Endocrine Reviewes 11 177-199.

Graham KE, Nusser KD \& Low MJ 1999 LßT2 gonadotroph cells secrete follicle stimulating hormone (FSH) in response to activin A. Fournal of Endocrinology $162 \mathrm{R} 1-5$.

Huttner WB \& Natori S 1995 Regulated secretion: Helper proteins for neuroendocrine secretion. Current Biology 5 242-245.

Kaiser UB, Sabbagh E, Katzenellenbogen RA, Conn PM \& Chin WW 1995 A machanism for the differential regulation of gonadotropin subunit gene expression by gonadotropin-releasing hormone. PNAS 92 12280-12284.

Kim T, Tao-Cheng JH, Eiden LE \& Loh YP 2002 Large dense-core secretory granule biogenesis is under the control of chromogranin A in neuroendocrine cells. Annals of the New York Academy of Sciences $971323-331$. 
Lapthorn AJ, Harris DC, Littlejohn A, Lustbader JW, Canfield RE, Machin KJ, Morgan FJ \& Isaacs NW 1994 Crystal structure of human chorionic gonadotropin. Nature 369 455-461.

Liu YC, Kato Y, Inoue K, Tanaka S \& Kurosumi K 1988 Co-localization of LH $\beta$ and FSH $\beta$ mRNAs in the porcine anterior pituitary by in situ hybridization with biotinylated probes. Biochemical Biophysical Research Communications 154 80-90.

Lloyd JM \& Childs GV 1988 Differential storage and release of luteinizing hormone and follicle-releasing hormone from individual gonadotropes separated by centrifugal elutriation. Endocrinology 122 1282-1290.

McNeilly AS 1988 The control of FSH secretion. Acta Endocrinologica Supplementum (Copenhagen) 288 31-40.

McNeilly AS, Crawford JL, Taragnat C, Nicol L \& McNeilly JR 2003 The differential secretion of FSH and LH: regulation through genes, feedback and packaging. Reproduction supplement $\mathbf{6 1}$ $1-14$.

McNeilly JR, Brown P, Clark AJ \& McNeilly AS 1991 Gonadotrophin-releasing hormone modulation of gonadotrophins in the ewe: evidence for differential effects on gene expression and hormone secretion. Fournal of Molecular Endocrinology 7 35-43.

McNeilly JR, Brown P, Mullins J, Clark AJ \& McNeilly AS 1996 Characterization of the ovine LH $\beta$-subunit gene: the promoter is regulated by $\mathrm{GnRH}$ and gonadal steroids in transgenic mice. Journal of Endocrinology 151 481-489.

Miller WL, Shafiee-Kermani F, Strahl BD \& Huang H-J 2002 The nature of FSH induction by GnRH. Trends in Endocrinology and Metabolism 13 257-263.

Muyan M, Ryzmkiewicz DM \& Boime I 1994 Secretion of lutropin and follitropin from transfected GH3 cells: evidence for separate secretory pathways. Molecular Endocrinology 8 1789-1797.

Nicol L, McNeilly JR, Stridsberg M, Crawford JL \& McNeilly AS 2002 Influence of steroids and GnRH on biosynthesis and secretion of secretogranin II and chromogranin A in relation to LH release in L $\beta$ T2 gonadotroph cells. Fournal of Endocrinology 174 473-483.

Padmanabhan V \& McNeilly AS 2001 Is there an FSH-releasing factor? Reproduction 121 21-30.

Padmanabhan V, McFadden K, Mauger DT, Karsch FJ \& Midgley AR Jr 1997 Neuroendocrine control of follicle-stimulating hormone (FSH) secretion. I. Direct evidence for separate episodic and basal components of FSH secretion. Endocrinology 138 $424-432$.

Pernasetti F, Vasilyev VV, Rosenberg SB, Bailey JS, Huang H-J, Miller WL \& Mellon PL 2001 Cell-specific transcriptional regulation of follicle-stimulating hormone-beta by activin and gonadotropin-releasing hormone in the L $\beta \mathrm{T} 2$ pituitary gonadotrope cell model. Endocrinology $1422284-2295$.

Portela Gomes GM \& Stridsberg M 2001 Selective processing of chromogranin A in the different islet cells in human pancreas. Fournal of Histochemistry and Cytochemistry 49 483-490.

Strahl BD, Huang H-J, Sebastian J, Ghosh BR \& Miller WL 1998 Transcriptional activation of the ovine follicle stimulating hormone beta-subunit gene by gonadotrophin-releasing hormone: involvement of two activating protein-1-binding sites and protein kinase C. Endocrinology 139 4455-4465.

Stridsberg M, Oberg K, Li Q Engstrom U \& Lundqvist G 1995 Measurements of chromogranin A, chromogranin B (secretogranin I), chromogranin $\mathrm{C}$ (secretogranin II) and pancreastatin in plasma and urine from patients with carcinoid tumours and endocrine pancreatic tumours. Fournal of Endocrinology 144 49-59.

Thomas SG \& Clarke IJ 1997 The positive feedback action of estrogen mobilizes LH-containing, but not FSH-containing secretory granules in ovine gonadotropes. Endocrinology 138 1347-1350.

Turgeon JL, Kimura Y, Waring DW \& Mellon PL 1996 Steroid and pulsatile gonadotropin-releasing hormone $(\mathrm{GnRH})$ regulation of luteinizing hormone and GnRH receptor in a novel gonadotrope cell line. Molecular Endocrinology 10 439-450.

Vale W, Rivier C, Hsueh A, Campen C, Meunier H, Bicsak T, Vaughan J, Corrigan A, Bardin W, Sawchenko P, Petraglia F, Yu J, Plotsky P, Spiess J \& Rivier J 1988 Chemical and biological characterization of the inhibin family of protein hormones. Recent Progress in Hormone Research 44 1-37.

Watanabe T, Uchiyama Y \& Grube D 1991 Topology of chromogranin A and secretogranin II in the rat anterior pituitary: potential marker proteins for distinct secretory pathways in gonadotrophs. Histochemistry 96 285-293.

Watanabe T, Jeziorowski T, Wuttke W \& Grube D 1993 Secretory granules in hyperstimulated male rat gonadotropes. Fournal of Histochemistry and Cytochemistry 41 1801-1812.

Watanabe T, Azuma T, Banno T, Jeziorowski T, Ohsawa Y, Waguri S, Grube D \& Uchiyama Y 1998 Immunocytochemical localization of chromogranin A and secretogranin II in female rat gonadotropes. Archives of Histology and Cytology 61 99-113.

Weiss J, Harris PE, Halvorsen LM, Crowley WF Jr \& Jameson JL 1992 Dynamic regulation of follicle-stimulating hormone- $\beta$ messenger ribonucleic acid levels by activin and gonadotrophin-releasing hormone in perifused rat pituitary cells. Endocrinology 131 1403-1408.

Weiss J, Crowley WFJ, Halvorson LM \& Jameson JL 1993 Perifusion of rat pituitary cells with gonadotropin-releasing hormone, activin, and inhibin reveals distinct effects on gonadotropin gene expression and secretion. Endocrinology 132 2307-2311.

Yoo SH 1996 pH- and $\mathrm{Ca}^{2+}$-dependent aggregation property of secretory vesicle matrix proteins and the potential role of chromogranins $\mathrm{A}$ and $\mathrm{B}$ in secretory vesicle biogenesis. Fournal of Biological Chemistry 271 1558-1565.

Yoo SH \& Jeon CJ 2000 Inositol 1,4,5-trisphosphate receptor/Ca ${ }^{2+}$ channel modulatory role of chromogranin $\mathrm{A}, \mathrm{a} \mathrm{Ca}^{2+}$ storage protein of secretory granules. Fournal of Biological Chemistry $\mathbf{2 7 5}$ 15067-15073.

Received in final form 12 December 2003
Accepted 22 December 2003 